\title{
La relevancia epistemológica de la perspectiva cultural y cosmovisión subyacente en los modismos. Un ámbito ejemplar: la vestimenta
}

\section{The Epistemological Relevance of the Cultural Perspective and Worldview Underlying Idioms.} An Exemplary Field: Clothing

\section{Peng Liu y Ana M. González Fernández \\ Universidad de Estudios Internacionales de Beijing 15010051900@163.com / ana@gonzalez.nu}

Recibido: abril-2020. Revisado: mayo-2020. Aceptado: junio-2020.

Resumen: Partiendo de la traducción español-chino de los modismos, específicamente en el ámbito de la vestimenta, analizamos las divergencias y convergencias entre estas fórmulas lingüísticas con el propósito de revelar las tradiciones o percepciones culturales subyacentes, así como sus correspondientes metáforas estructurales privativas, que determinarán la siempre dificultosa elección por parte del traductor de las estrategias pertinentes para el trasvase efectivo de los modismos de una lengua a otra: transliteración, domesticación o extranjerización. Consecuentemente, la traducción de modismos va a implicar necesariamente la identificación, comprensión e interiorización de la perspectiva cultural de la comunidad hablante de esa lengua y de su cosmovisión, repertorio valórico o creencias básicas, por lo que, el traductor, en su labor, ha de asumir su crucial papel como agente mediador o modulador intercultural.

Peng Liu y Ana M. González Fernández La relevancia epistemológica de la perspectiva cultural y cosmovisión subyacente en los modismos... 
Palabras clave: traducción; modismos; perspectiva cultural; metáfora; chino-español; modismos de vestimenta.

\begin{abstract}
From the perspective of the Spanish-Chinese translation of idioms - specifically in the field of clothing - , we analyze the divergences and convergences between these linguistic formulas in order to reveal the underlying cultural traditions or perceptions, as well as their corresponding proprietary structural metaphors, which will determine the translator's always difficult choice of the pertinent strategies for the effective transfer of idioms from one language to another: transliteration, domestication or foreignization. Consequently, the translation of idioms will necessarily involve the identification, understanding and internalization of the cultural perspective of the community that speaks that language and its worldview, value repertoire or basic beliefs, which is why translators, in their work, have to assume their crucial role as intercultural mediators or modulators.
\end{abstract}

Keywords: translation; idioms; cultural perspective; metaphor; Chinese-Spanish; clothing idioms.

\title{
1. OBJETIVO DEL PRESENTE ESTUDIO
}

Los modismos se erigen como expresiones fijas, privativas de una lengua, cuyo significado no es deducible a partir de las palabras que las forman. Estas expresiones exocéntricas reflejan los hábitos, conceptos o experiencias únicas de un pueblo, su acervo cultural y cosmovisión idiosincrásica conformada acumulativamente a lo largo del transcurrir histórico. Los modismos condensan y expresan esta informaciónherencia a través de cierta forma o estructura lingüística, la cual se cimenta sobre un repertorio de imágenes concretas.

Tomando como referencia la traducción español-chino de los modismos y centrándonos en el caso concreto del ámbito de la vestimenta, el presente artículo analiza y resume las divergencias y convergencias entre los modismos chinos y españoles en dicho ámbito y al mismo tiempo revela, al analizar las metáforas estructurales tras estas lexías complejas o culturemas fraseológicos, las tradiciones o percepciones culturales únicas que subyacen a estos en cada lengua, con el fin de desarrollar unas estrategias adecuadas para la traducción de los modismos de una lengua a la otra.

Las divergencias entre los modismos del ámbito de la vestimenta en ambas lenguas se manifiestan en varios planos. En primer lugar, las formas de estructuración a las que responden difieren notablemente. El núcleo léxico estructural de los modismos españoles se inviste de rasgos concretos y físicos mientras que el de los modismos chinos prioriza rasgos cualitativos. Segundo, los de cada lengua atesoran matices particulares que tienen raigambre en su trasfondo cultural idiosincrásico y privativo.

Peng Liu y Ana M. GonzÁlez Fernández La relevancia epistemológica de la perspectiva cultural y cosmovisión subyacente en los modismos...
CLINA

vol. 6-1, June 2020, 127-146

elSSN: 2444-1961

Ediciones Universidad de Salamanca - CC BY-NC-ND 
Tercero, los modismos del chino y del español en torno a la vestimenta se edifican sobre sus propias metáforas estructurales, que solo en escasas ocasiones convergen en ambas lenguas.

\section{HALLAZGOS EMPÍRICOS EN TORNO A LAS DIVERGENCIAS Y CONVERGENCIAS ENTRE LOS MODISMOS CHINOS Y ESPAÑOLES EN EL ÁMBITO DE LA VESTIMENTA}

La primera divergencia que resulta evidente es que las formas de estructuración de los modismos en ambas lenguas difieren notablemente en cuanto al elemento nuclear, es decir, al elegido como eje léxico del modismo, tendiendo respectivamente en cada una de ellas a polarizarse hacia la abstracción o la concreción. Esta diferente predilección se pone de manifiesto, por ejemplo, en que los conceptos prototípicos contenidos en los modismos españoles relativos a la vestimenta se asocian prioritariamente a elementos de vestimenta concretos y físicos, figurando así lingüísticamente explícito el término de la prenda en cuestión: gorra, guante, chaqueta, zapato, etc. (véase la Tabla 1); mientras, los conceptos capitales en los modismos chinos del ámbito de la vestimenta se asocian más bien a dimensiones cualitativas propias y definitorias de la vestimenta, tales como su cromatismo, el estilo, el grado de ornamento que presentan o el material de confección. Como se puede observar en la Tabla 2, seis de los modismos chinos recogidos de este ámbito presentan elementos cromáticos, entre los que se encuentran el rojo, los tonos ocres y rojizos, el verde, el blanco, el negro, el oro, el púrpura... En cuanto a los materiales de las prendas señalados, se encuentran la seda, el lino, las plumas, el algodón, etc.

La prevalencia de una visión holística de la realidad sobre una analítica define el acercamiento perceptivo de los orientales al mundo que los rodea. Por esta razón, no resulta sorprendente que la prenda en sí no constituya, en chino, el primer elemento referencial, sino que lo sean cualidades genéricas y/o específicas de las mismas. Tampoco resulta sorprendente que, en español, la prenda concreta, aislada, constituya el punto de partida referencial. Naturalmente, hablamos de orientación predominante o tendencia mayoritaria, puesto que en ambas lenguas podríamos encontrar algún ejemplo de modismo protagonizado por un rasgo cualitativo o por uno concreto o físico: p. ej., con un material como la seda en español («ir como la seda», «estar como una seda»,...) O, en chino, con la prenda propiamente dicha: 勒紧裤腰带 («apretarse el cinturón»), 戴绿帽子 («ponerse[le] una gorra verde», en alusión al varón que sufre la infidelidad femenina), 穿小鞋 («ponerle zapatitos o zapatos pequeños a alguien», en referencia al superior que, por antipatía, obstaculiza el trabajo o la promoción de su subordinado), etc.

Peng Liu y Ana M. GonzÁlez Fernández La relevancia epistemológica de la perspectiva cultural y cosmovisión subyacente en los modismos...
CLINA

vol. 6-1, June 2020, 127-146

elSSN: 2444-1961

Ediciones Universidad de Salamanca - CC BY-NC-ND 
Tabla 1. Núcleo léxico estructural de los modismos españoles

en torno a la vestimenta: rasgos concretos y físicos

\begin{tabular}{|c|c|}
\hline $\begin{array}{l}\text { Término nuclear de modismos españoles } \\
\text { de vestimenta / prendas }\end{array}$ & Ejemplos de modismos \\
\hline gorra & De gorra \\
\hline gorro & Hasta el gorro \\
\hline chaqueta & Cambiar de chaqueta \\
\hline guante & $\begin{array}{l}\text { Como un guante/ Echar el guante/ De guante } \\
\text { blanco }\end{array}$ \\
\hline pantalones & Llevar los pantalones/ Bajarse los pantalones \\
\hline sombrero & Quitarse el sombrero \\
\hline zapatos & $\begin{array}{l}\text { Ponerse en los zapatos de alguien/ Apretarle a } \\
\text { alguien el zapato/ Como un niño con zapatos } \\
\text { nuevos }\end{array}$ \\
\hline botas & Ponerse las botas \\
\hline faldas & Líos de faldas \\
\hline camisa & $\begin{array}{l}\text { No llegarle a alguien la camisa al cuello/ } \\
\text { Meterse en camisas de once varas }\end{array}$ \\
\hline camiseta & Mojar la camiseta \\
\hline cinturón & Apretarse el cinturón \\
\hline capa & Hacer de su capa un sayo/ De capa caída \\
\hline calzón & Ser un calzonazos \\
\hline
\end{tabular}

Tabla 2. Núcleo léxico estructural de los modismos chinos en torno a la vestimenta: rasgos cualitativos

\begin{tabular}{|c|c|}
\hline $\begin{array}{l}\text { Término nuclear de modismos } \\
\text { chinos de vestimenta / cualidad }\end{array}$ & Ejemplos de modismos (transliteración) \\
\hline color & $\begin{array}{l}\text { 穿红着绿 (vestirse de rojo y verde), 青衣乌帽 (ponerse } \\
\text { ropa y sombrero negros), 白衣宰相 (primer ministro de } \\
\text { blanco), 腰金衣紫 (colgar un sello de oro a la cintura y } \\
\text { vestirse con traje de color púrpura), 白日衣绣 (ataviarse } \\
\text { de día con ropa bordada y colorida), 赫衣塞路 (gente } \\
\text { vestida en tonos ocre llena la calle) }\end{array}$ \\
\hline Material 1: seda & $\begin{array}{l}\text { 锦衣玉食 (ropa de seda y comida en recipientes de } \\
\text { jade), 衣锦还乡 (volver al pueblo natal con ropa de seda) }\end{array}$ \\
\hline Material 2: algodón & $\begin{array}{l}\text { 布衣之交 (amigos con ropas de tela), 褐衣不完 (ropas } \\
\text { de tela basta y hechura descuidada) }\end{array}$ \\
\hline Material 3: lino & 披麻戴孝 (vestirse de lino y tocado de luto) \\
\hline Material 4: plumas & 鸿衣羽裳 (vestimenta con penachos de plumas) \\
\hline
\end{tabular}

Peng Liu y Ana M. GonzÁlez Fernández La relevancia epistemológica de la perspectiva cultural y cosmovisión subyacente en los modismos... 
Los experimentos del psicólogo cultural Takahiko Masuda (Masuda y Nisbett 2001, 922-934) en torno a las diferencias perceptivas y de categorización entre orientales y occidentales apuntan inequívocamente en esta línea: el oriental adopta como forma mental la inducción (yendo desde lo particular hasta lo genérico y estableciendo relaciones orgánicas e interdependientes entre los objetos), mientras que el occidental parte de esquemas generales prefijados para deductivamente llegar a la determinación de los elementos secundarios o a cualidades definitorias (mostrando predilección por los sustantivos, pues categorizan y contienen la esencia del objeto aislado y con independencia del contexto o entorno).

Si atendemos a la concepción de Humboldt (1836) en torno a la relación entre lenguaje y pensamiento, al papel vehiculizador de la primera con respecto al segundo, sin entrar en el transitado debate en torno a las hipótesis Sapir-Whorf (Hoijer 1954, 92-105), el español y el chino, en sus respectivas expresiones fraseológicas, corporizan, a través de la función taxonómica del lenguaje, diferentes clasificaciones y acercamientos al mundo sensible que hallan su reflejo, en este caso, en los modismos. Recordemos también, dada la estrecha vinculación de la oralidad con el modismo en su nacimiento y transmisión, las palabras de Aristóteles (384-322 a. C.): «Las palabras habladas son símbolos de afecciones o impresiones del alma; las palabras escritas son los signos de las palabras habladas».

Retornando a nuestras observaciones, la segunda divergencia notable hallada en la comparativa es que los modismos en torno a la vestimenta, en cada uno de estos dos idiomas, atesoran sus particulares matices, relacionados principalmente con dimensiones culturales definitorias de sus respectivas culturas y asociaciones prototípicas derivadas de los valores predominantes dentro de cada una de las mencionadas categorizaciones culturales. Sirva como referencia para emprender una comparativa entre culturas el puntaje asignado por Geert Hofstede (2001) a China y España en cada una de las seis dimensiones por él establecidas.

Así, los modismos españoles en el ámbito de la vestimenta reflejan matices valóricos psicosociales diversos, tales como el grado de perfección o conveniencia, el grado de implicación o costo, la admiración o reconocimiento, la ostentación de poder, el grado de autoconciencia o empatía, el autocontrol, el donjuanismo, etc. (véase la Tabla 3); por su parte, los modismos chinos en este campo de la ropa contienen matices culturales valóricos más limitados, restringidos sobre todo al ámbito de la distancia jerárquica, a la asunción de la inequidad por parte de la población o de las diferencias de poder que implican diferentes estatus, pertenencia de clase y percepciones sociales (véase la Tabla 4).

Peng Liu y Ana M. GonzÁlez Fernández La relevancia epistemológica de la perspectiva cultural y cosmovisión subyacente en los modismos...
CLINA

vol. 6-1, June 2020, 127-146

elSSN: 2444-1961

Ediciones Universidad de Salamanca - CC BY-NC-ND 


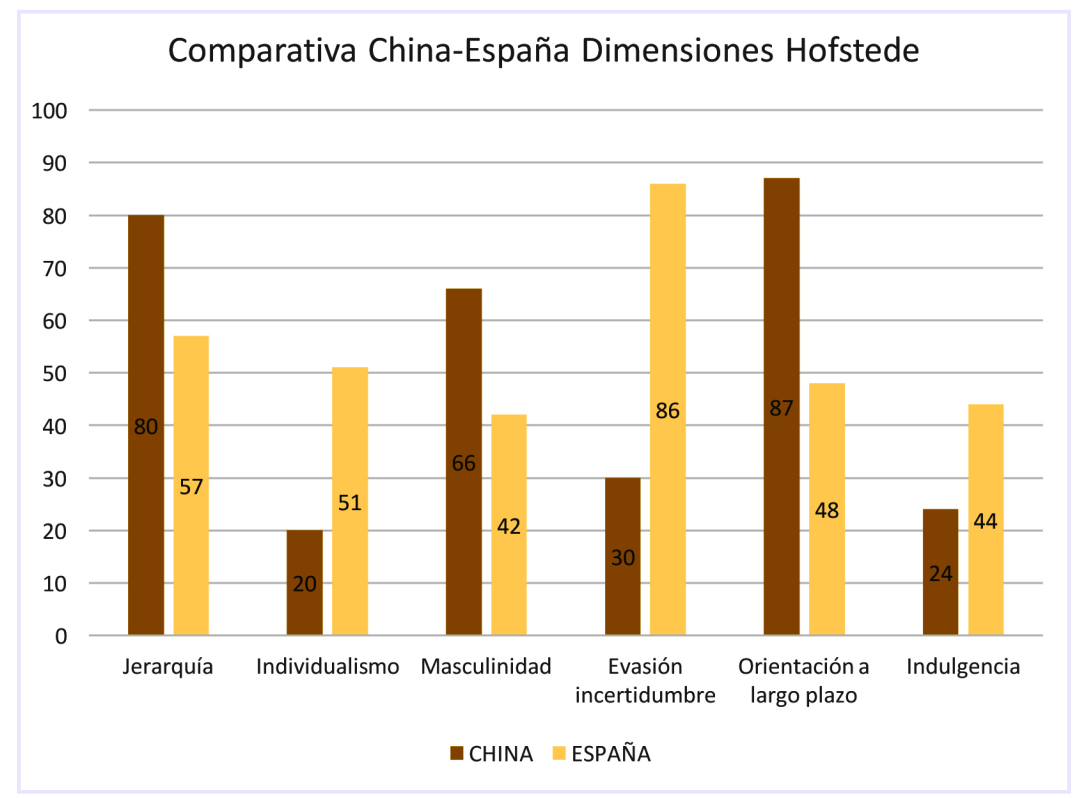

Gráfico 1. China-España a la luz de las dimensiones culturales de Hofstede

Tabla 3. Diversidad de matices valóricos y psicosociales contenidos en los modismos españoles en torno a la vestimenta

\begin{tabular}{|c|c|c|}
\hline N..$^{\circ}$ & Matices culturales & Ejemplos de modismos \\
\hline 1 & seda: perfección/ conveniencia & $\begin{array}{l}\text { Ir como la seda/ estar como una seda/ } \\
\text { vestirse de seda }\end{array}$ \\
\hline 2 & $\begin{array}{l}\text { prenda: costo/ grado de implicación- } \\
\text { colaboración }\end{array}$ & $\begin{array}{l}\text { No doler prendas/ no soltar prenda/ ser un } \\
\text { prenda }\end{array}$ \\
\hline 3 & sombrero: admiración, reconocimiento & Quitarse el sombrero \\
\hline 4 & pantalones: poder, intereses & $\begin{array}{l}\text { Llevar los pantalones, bajarse los } \\
\text { pantalones }\end{array}$ \\
\hline 5 & zapatos: circunstancias & $\begin{array}{l}\text { Ponerse en los zapatos de alguien/ saber } \\
\text { dónde le aprieta el zapato }\end{array}$ \\
\hline 6 & cinturón: autocontrol o autorrestricción & Apretarse el cinturón \\
\hline 7 & faldas: mujer sensual o bella/ donjuanismo & Líos de faldas \\
\hline 8 & chaqueta: posición & Cambiar de chaqueta \\
\hline 9 & guante: captura/ desafío & Echar el guante/ lanzar el guante \\
\hline 10 & camiseta: trabajo/ energía & Mojar la camiseta \\
\hline
\end{tabular}

Peng Liu y Ana M. GonzÁlez Fernández La relevancia epistemológica de la perspectiva cultural y cosmovisión subyacente en los modismos... 
Tabla 4. Matices culturales de valores jerárquicos contenidos en los modismos chinos de vestimenta

Ejemplos de modismos (transliteración)

青衣乌帽 (ponerse ropa y sombrero negros)

\section{Explicación sobre el matiz de jerarquía}

Para indicar que el estilo de vestir es propio de las personas de clase baja, de los más humildes.

De referencia legendaria, para calificar el acto del emperador chino de salir a la sociedad escondiendo, a través del atavío, su identidad y estatus reales para conocer el verdadero nivel de vida del pueblo.

Para calificar el acto de pavonearse ante los paisanos del pueblo después de haberse enriquecido u obtenido un alto cargo.

Para calificar el acto de obtener un cargo muy alto en el gobierno.

安金衣紫 (colgar un sello de oro en
vestirse con traje de color púrpura)

白日衣绣 (vestirse con ropa bordada y colorida de día)

赫衣塞路 (gente con ropa rojiza llena la calle)

只重衣衫不重人 (solo fijarse en la ropa en vez de en la persona propiamente dicha)

弹冠振衣 (limpiar el tocado y el traje)

鸿衣羽裳 (vestimenta con plumas)

振衣濯足 (limpiar la ropa y lavarse los pies)

Para calificar el acto de hacer ostentación de riqueza o de un alto cargo ante los paisanos.

En referencia a un grupo de prisioneros (antiguamente los convictos se vestían con ropas de color rojizo).

Para referirse a la concesión de mayor importancia al aspecto que a las cualidades personales.

Para referirse al acto de planear de forma codiciosa el ocupar un cargo.

En alusión a la vestimenta de las deidades.

Para referirse al acto de abandonar riquezas y cargos altos para dedicarse a una vida modesta y sencilla.

En referencia a alguien común y corriente pero que tiene parientes ocupando altos cargos, y aprovecha la influencia de estos últimos para conseguir beneficios indebidos; nepotismo, en definitiva.

Dentro de esa variopinta multiplicidad de implicaturas que caracterizan a los modismos en la lengua española, en la casuística que nos ocupa cabe citar como ejemplo revelador que pone de manifiesto la vertiente del individualismo en cuanto al matiz de costo personal o grado de involucración y compromiso que implica el acometimiento de una acción. El modismo «no doler prendas» significa "cumplir fielmente con sus obligaciones y no reparar en gastos o recursos para lograr un fin». En este sentido,

Peng Liu y Ana M. González Fernández La relevancia epistemológica de la perspectiva cultural y cosmovisión subyacente en los modismos... 
implica tácitamente un sacrificio del «yo» o una concesión desde la individualidad por lo general irrenunciable (entendida la "prenda» como una extensión del «yo»). No es casualidad que el término se relacione etimológicamente con «empeñar» y «desempeñar», con «dar garantías». En sentido contrario, encontramos «no soltar prenda», que indica la ausencia de colaboración informativa, la negativa a hablar y revelar alguna información o conocimiento que el interlocutor demanda del sujeto. El mismo término «prenda» lo encontramos en usos más populares o coloquiales con significados como «persona amada» o «sujeto peculiar», donde se da una metonimia de la parte por el todo (la prenda por la persona), en sentido positivo en el primer caso y negativo en el segundo.

El modismo «quitarse el sombrero», el cual significa «expresar reverencia o admiración por una acción digna de alabanza», cristaliza un gesto que se remonta a la época romana de despojarse de ciertas prendas en muestra de reconocimiento y respeto hacia otro, encerrando inequívocamente el matiz de admiración e implicando, desde la individualidad, el reconocimiento de la valía de otra individualidad o de sus actos. De igual manera, como reflejo de un puntaje en la dimensión individualismo/colectivismo 30 puntos por encima de China en cuanto a preponderancia del «yo» frente al «nosotros», encontramos también este valor en algunos de los modismos en torno a «zapatos»: «ponerse en los zapatos de alguien» se asocia a una renuncia temporal de la perspectiva ostentada por el «yo» hablante para intentar comprender la coyuntura de otro sujeto, validando así su individualidad. Sin embargo, "cada uno sabe dónde le aprieta el zapato» supone tirar la toalla respecto a esa potencial comprensión de las circunstancias concretas de otro "yo», validando de esta manera la convicción de que es el propio sujeto el que ostenta de forma exclusiva el conocimiento, parafraseando a Ortega y Gasset, de sí mismo y sus circunstancias.

En cambio, en chino, en cuanto a la dimensión de la distancia al poder (una de las más marcadas e idiosincrásicas de esta cultura asiática), abundan modismos en torno a la vestimenta que implican valores jerárquicos, símbolos de estatus y privilegio, lo cual es reflejo de una concepción filosófica donde «procedencia» y «precedencia» organizan la vida del individuo en un colectivo social que es el que, a través de la integración y de un incuestionable e indisoluble compromiso bidireccional, dota de significado y valor a su propia existencia. Con un puntaje de 80 en esta dimensión, China se sitúa entre uno de los países más jerárquicos del mundo.

Cuando hablamos de jerarquía o distancia al poder hacemos referencia al grado de aceptación por parte de la sociedad de una distribución desigual del poder, de estatus polarizados y, en definitiva, de la aceptación y obediencia por parte de la mayoría, además de a la tradición, a la autoridad de grupos reducidos. Indicadores prototípicos de dicha alta distancia jerárquica serían: sobrecarga laboral y ambigüedad o polivalencia de roles, acatamiento de órdenes, énfasis en la obediencia y en la evasión del conflicto argumentativo, aversión a la iniciativa personal, interdependencia de la mayoría respecto a la minoría, respeto y temor a la autoridad, asunción de la existencia de privilegios

Peng Liu y Ana M. González FeRnández La relevancia epistemológica de la perspectiva cultural y cosmovisión subyacente en los modismos...
CLINA

vol. 6-1, June 2020, 127-146

elSSN: 2444-1961

Ediciones Universidad de Salamanca - CC BY-NC-ND 
para los poderosos, diferencias existenciales evidenciadas en ostentaciones privativas de estatus, fronteras desdibujadas entre la vida personal y profesional o laboral, etc.

Como era de esperar, la importancia de la jerarquía en la cultura china, como pilar que sustenta una realidad social colectivista y la interacción entre los sujetos desde su nacimiento, se refleja no solo en los modismos relativos a la vestimenta, sino también en otros muchos, como por ejemplo: 一阶半级 (“un rango y medio grado», en referencia a aquellos que ocupan los escalafones más bajos); 红墙绿瓦 («muros rojos y tejas verdes», en referencia a aquellos edificios con un estatus superior o privilegiado). Por supuesto, en el español también encontramos reflejos lingüísticos del concepto de poder y de su ostentación, pero su presencia es radicalmente inferior, con menor relevancia e impregnando de manera sutil la realidad integral de un individuo del que no se enfatiza su pertenencia o asignación a un determinado estrato social fácilmente reconocible por los demás («llevar los pantalones», «sacarse el cinturón», «cortar el bacalao», «tener la sartén por el mango», etc.).

Veamos algunos ejemplos del chino: 青衣乌帽 («ataviarse con ropa y sombrero negros») alude de forma inequívoca a la gente de clase baja; es decir, a través de una indumentaria específica se identifica la pertenencia del individuo a una clase social (en este caso, de las más desfavorecidas y, por lo tanto, con menor acceso al poder y con mayor grado de subordinación); 腰金衣紫 («colgar un sello de oro a la cintura y vestirse con traje de color púrpura»), por el contrario, se refiere a los altos oficiales y permite ver cómo el ornato y la elección cromática responden privativamente a la pertenencia a un estatus social y jerárquico (en este caso, con una acumulación socialmente aceptada de poder); 赫衣塞路 («gente con ropa rojiza o de tonos ocre llena la calle») hace referencia a un estatus social muy específico, el de los prisioneros, y pone de manifiesto nuevamente cómo el cromatismo indumentario y el estatus social se hallan estrechamente interrelacionados y constituyen un elemento identificativo inequívoco colectivamente aceptado; 鸿衣羽裳 («vestimenta con penachos de plumas») alude a las deidades, al atuendo de los dioses.

Sin duda, subyace como razón una tradición histórica por la cual la vestimenta y la elección de la indumentaria se relaciona estrechamente con la estructuración jerárquica de la sociedad y encuentra su reflejo en los modismos chinos: las dinastías feudales que gobernaron concatenadamente China duraron más de dos mil años y el mandato de los emperadores chinos se basaba en estrictas instituciones jerárquicas y en el sometimiento de los grupos sociales al estatus correspondiente. La estrecha relación del dominio de la vestimenta con el del estatus social en chino se atribuye, muy probablemente, a los reglamentos establecidos en la antigua sociedad feudal sobre la vestimenta para personas de distintas clases sociales, los que, en muchos casos, asignaban determinados colores de ropa a determinados rangos y categorías. En la dinastía Tang de China (618-907), los funcionarios que ocupaban cargos de categoría superior al nivel 3 se vestían de túnica talar de color púrpura; para los de cargos de categoría superior al nivel 5, de color carmesí; para los de cargos de categoría inferior al nivel 6 , de color verde.

Peng Liu y Ana M. GonzÁlez Fernández La relevancia epistemológica de la perspectiva cultural y cosmovisión subyacente en los modismos...
CLINA

vol. 6-1, June 2020, 127-146

elSSN: 2444-1961

Ediciones Universidad de Salamanca - CC BY-NC-ND 
La tercera divergencia descubierta a lo largo de esta comparativa es que los modismos de vestimenta del chino y del español remiten a metáforas estructurales diferentes y distintivas para expresar un mismo significado (véase la tabla 5).

Según la teoría experiencialista de la metáfora de Lakoff y Johnson, las metáforas estructurales hacen referencia a los conceptos construidos metafóricamente a partir de la estructura de conceptos originales, reflejando diferencias entre los modelos cognitivos y lógicos, al constituir ellas mismas un omnipresente modelo de cognición y una guía de percepción, acción e interacción con el mundo circundante: «Nuestro sistema conceptual ordinario, en términos del cual pensamos y actuamos, es fundamentalmente de naturaleza metafórica» (Lakoff y Johnson 1986, 39). Esto es, las metáforas, transcendiendo la dimensión formal del lenguaje, estructuran, en función de la experiencia vital, la interacción con el mundo circundante y el trasfondo cultural, conceptos sobre otros conceptos.

Por ejemplo, el modismo español «echar el guante» tiene el significado de «apresar a una persona (delincuente)». Este modismo construye un marco metafórico de "guante-esposa» a partir de marcadas reminiscencias históricas (parte de la indumentaria de las fuerzas del orden público desde la Edad Media, con el valor simbólico de retar al adversario o de entregarse en la derrota en un duelo). Los guantes, según el modelo cognitivo de un lector chino, son una mera prenda para cubrir las manos, y los chinos no vinculan los guantes con acciones como aprisionar o cazar, que se vinculan con objetos como la cuerda, por lo cual el equivalente chino de este modismo español puede ser 绳之以法 ("arrestar con una cuerda según la ley»).

Otro ejemplo sería cambiar de chaqueta, que significa un «cambio radical de posición, generalmente política». Aquí se esconde, también con marcadas y claras raíces históricas, un marco metafórico para un lector español de "chaqueta-posición». Los posicionamientos son susceptibles de cambio en cualquier momento, característica compartida por las chaquetas, que pueden ser mudadas a diario. En cambio, para expresar el mismo significado, el chino posee su propio marco metafórico: «bandera (o portal) - posición». La palabra china 门庭 («portal») se refiere al linaje o estatus social de cierta familia. Por eso, cambiar de bandera o de portal, en chino, significa cambiar de posición. Como resultado, "cambiar de chaqueta» en español se podría traducir al chino como 改旗易帜 (“cambiar de bandera») O 改换门庭 (“cambiar de portal»).

Sin embargo, citadas ya algunas de las numerosas divergencias existentes, tal y como nos haría presuponer la marcada distancia cultural y de cosmovisión entre las lenguas que nos ocupan, en algunos casos observamos que, sin embargo, convergen las metáforas estructurales en los dos idiomas para expresar un mismo significado (véase la tabla 6). Por ejemplo, el modismo español «apretarse el cinturón» construye el marco metafórico de «cinturón-ganas/deseos» y su significado es «reducir» o «ajustar el gasto». El cinturón, de acuerdo con el modelo cognitivo de un hablante hispano, se vincula a conceptos como "ganas" o "deseos", debido a que tanto el cinturón como las ganas, las ansias del ser humano, tienen la característica de ser ajustables

Peng Liu y Ana M. González FernándeZ La relevancia epistemológica de la perspectiva cultural y cosmovisión subyacente en los modismos...
CLINA

vol. 6-1, June 2020, 127-146

elSSN: $2444-1961$

Ediciones Universidad de Salamanca - CC BY-NC-ND 
o regulables. Casualmente, los chinos comparten este modelo cognitivo: el modismo chino 勒紧裤腰带 («apretarse el cinturón») expresa idéntico significado.

Tabla 5. Ejemplos de divergencia entre metáforas estructurales en los modismos de vestimenta españoles y sus correspondientes chinos

\begin{tabular}{|c|c|c|c|}
\hline N. ${ }^{\circ}$ & Significado & $\begin{array}{l}\text { Modismos } \\
\text { españoles y } \\
\text { sus metáforas } \\
\text { estructurales }\end{array}$ & $\begin{array}{c}\text { Modismos chinos y sus metáforas } \\
\text { estructurales }\end{array}$ \\
\hline 1 & $\begin{array}{l}\text { Funcionar o } \\
\text { desenvolverse } \\
\text { perfectamente. } \\
\text { Ir sin problemas ni } \\
\text { obstáculos. }\end{array}$ & $\begin{array}{l}\text { Como la seda: } \\
\text { 1. seda-perfección } \\
\text { 2. seda-fluidez }\end{array}$ & $\begin{array}{l}\text { 遂心如意: cumplir con el deseo y la } \\
\text { voluntad. Corazón-perfección } \\
\text { 行云流水: como nube caminante y } \\
\text { agua fluyente. Nube y agua-fluidez }\end{array}$ \\
\hline 2 & $\begin{array}{l}\text { Cambio radical de } \\
\text { posición. }\end{array}$ & $\begin{array}{l}\text { Cambiar de } \\
\text { chaqueta: chaqueta- } \\
\text { posición }\end{array}$ & $\begin{array}{l}\text { 改换门庭: cambiar de portal. Portal- } \\
\text { posición }\end{array}$ \\
\hline 3 & $\begin{array}{l}\text { Capturar, apresar } \\
\text { a una persona, } \\
\text { especialmente a un } \\
\text { delincuente. }\end{array}$ & $\begin{array}{l}\text { Echar el guante: } \\
\text { guante-prisión }\end{array}$ & $\begin{array}{l}\text { 绳之以法: apresar a alguien con una } \\
\text { cuerda. Cuerda-prisión }\end{array}$ \\
\hline 4 & $\begin{array}{l}\text { Tener el mando, el } \\
\text { poder, ser el que tiene } \\
\text { la última palabra. }\end{array}$ & $\begin{array}{l}\text { Llevar los pantalones: } \\
\text { pantalones-poder }\end{array}$ & 拍板: tocar la claqueta. Claqueta-poder \\
\hline 5 & $\begin{array}{l}\text { Expresar reverencia } \\
\text { o admiración por } \\
\text { una acción digna de } \\
\text { alabanza. }\end{array}$ & $\begin{array}{l}\text { Quitarse el sombrero: } \\
\text { sombrero -admiración }\end{array}$ & $\begin{array}{l}\text { 五体投地: postrarse de rodillas tocando } \\
\text { el suelo con los codos y la cabeza. } \\
\text { Cuerpo-admiración }\end{array}$ \\
\hline 6 & $\begin{array}{l}\text { Esforzarse, luchar por } \\
\text { conseguir algo. }\end{array}$ & $\begin{array}{l}\text { Mojar la camiseta: } \\
\text { camiseta -trabajo/ } \\
\text { energía }\end{array}$ & $\begin{array}{l}\text { 撸起袖子: arremangarse. Manga- } \\
\text { trabajo }\end{array}$ \\
\hline 7 & $\begin{array}{l}\text { Ponerse en el lugar } \\
\text { de otro. }\end{array}$ & $\begin{array}{l}\text { Ponerse en } \\
\text { los zapatos de } \\
\text { alguien: zapatos- } \\
\text { circunstancias }\end{array}$ & $\begin{array}{l}\text { 将心比心: comparar corazón con } \\
\text { corazón. Corazón-circunstancias }\end{array}$ \\
\hline 8 & $\begin{array}{l}\text { Cumplir fielmente con } \\
\text { sus obligaciones, no } \\
\text { reparar en gastos o } \\
\text { recursos para lograr } \\
\text { un fin. }\end{array}$ & $\begin{array}{l}\text { No doler prendas: } \\
\text { prendas-costo }\end{array}$ & $\begin{array}{l}\text { 不惜血本: no importar un costo como } \\
\text { la sangre. Sangre-costo }\end{array}$ \\
\hline
\end{tabular}

Otro ejemplo lo proporciona el modismo español «líos de faldas», que se refiere a los líos en los que se mete un hombre por su afición desmedida a las féminas, en el cual se construye el marco metafórico de «faldas-mujer». Según los hablantes de

Peng Liu y Ana M. GonzÁlez Fernández La relevancia epistemológica de la perspectiva cultural y cosmovisión subyacente en los modismos... 
español, la falda se erige incluso en metonimia del género femenino. Justamente el modismo chino 石榴裙下 comparte este marco metafórico, cuyo origen se remonta a Yang Yuhuan, concubina favorita del emperador Li Longji, de la dinastía Tang ${ }^{1}$, y una de las "Cuatro Bellezas de la Antigua China». Así, este modismo chino manifiesta, por extensión, la rendición y el culto a la belleza de las mujeres. Sin embargo, no expresa el mismo significado que el modismo español porque este realmente enfatiza los problemas y líos en los que se mete un hombre por su afición a las mujeres bellas.

Tabla 6. Ejemplos de convergencia entre metáforas estructurales en los modismos de vestimenta españoles y chinos

\begin{tabular}{|c|l|l|l|l|}
\hline N. & $\begin{array}{l}\text { Los modismos } \\
\text { españoles y } \\
\text { sus metáforas } \\
\text { estructurales }\end{array}$ & Significado & $\begin{array}{c}\text { Los modismos chinos } \\
\text { y sus metáforas } \\
\text { estructurales }\end{array}$ & \multicolumn{1}{|c|}{ Significado } \\
\hline 1 & $\begin{array}{l}\text { Apretarse el } \\
\text { cinturón: cinturón- } \\
\text { ganas }\end{array}$ & $\begin{array}{l}\text { Reducir o } \\
\text { ajustar el gasto }\end{array}$ & $\begin{array}{l}\text { 勒紧裤腰带: cinturón- } \\
\text { ganas }\end{array}$ & $\begin{array}{l}\text { Reducir o ajustar el } \\
\text { gasto }\end{array}$ \\
\hline 2 & $\begin{array}{l}\text { Líos de faldas: } \\
\text { faldas-mujer bella }\end{array}$ & Donjuanismo & $\begin{array}{l}\text { 石榴裙下: faldas-mujer } \\
\text { bella }\end{array}$ & $\begin{array}{l}\text { Para referirse a las } \\
\text { mujeres muy bellas }\end{array}$ \\
\hline
\end{tabular}

\section{PROPUESTAS DE TRADUCCIÓN ENTRE LOS MODISMOS CHINOS Y ESPAÑOLES EN TORNO A LA VESTIMENTA}

Las actividades de traducción conforman una especie de relación tripartita, que involucra al autor/hablante de la lengua de origen, al traductor, y al lector/oyente de la lengua meta. Es así que el traductor asume una especie de doblete identitario en esta actividad, al erigirse tanto en receptor como en emisor de información, por lo que él es quien debe reflexionar sobre la intención del autor y seleccionar cierta forma lingüística de la lengua meta para transmitir en el mayor grado posible el significado del

1. Esta leyenda cuenta que, debido a que el emperador Li Longji de la dinastía Tang vivía embelesado con su concubina Yang, ignorando incluso los asuntos del gobierno, los ministros se mostraban enojados con Yang y se negaban a saludarla. El emperador sentía que su mujer estaba siendo ofendida, por lo que ordenó inmediatamente que todos los funcionarios, al ver a la concubina, tuvieran que arrodillarse. Así, cada vez que la concubina Yang se presentaba vestida de una falda de color granada, todos los cortesanos se arrodillaban ante ella. Por ello, la expresión coloquial "bajo la falda de color granada» se ha convertido en un modismo chino que señala el culto a la belleza de las mujeres.

Peng Liu y Ana M. González Fernández La relevancia epistemológica de la perspectiva cultural y cosmovisión subyacente en los modismos...
CLINA

vol. 6-1, June 2020, 127-146

elSSN: 2444-1961

Ediciones Universidad de Salamanca - CC BY-NC-ND 
texto origen, a fin de lograr así la equivalencia básica de significado tanto en el plano semántico como estilístico.

Considerando que los significados de los diferentes modismos, expresiones fijas de una lengua, no son deducibles a partir de las palabras que los forman, y que, en la gran mayoría de los casos, los hablantes de una lengua albergan sus propios modelos cognitivos y lógicos que se ven reflejados en las estructuras privativas de los modismos, resulta evidente la conveniencia pragmática de adoptar en muchos casos una estrategia de traducción de domesticación o naturalización cuando se traducen al chino los modismos españoles, en este caso en torno a la vestimenta, con el fin de transmitir fluidamente el mismo significado y conservar el estilo del texto original. De traducirse literalmente dichos culturemas, es muy probable que en los lectores chinos no se suscitasen las asociaciones y el razonamiento que se desencadenan en el hablante hispano, por lo que el lector chino no podría deducir con precisión el significado que se expresa a través de esas fórmulas lexicalizadas y lo recibiría con extrañeza.

Franco Aixelá (1996, 52-78) gradúa, de menor a mayor, las diferentes técnicas de traducción de elementos culturalmente específicos: desde aquellas de conservación, que tienden al mantenimiento del referente cultural (repetición, adaptación ortográfica, adaptación terminológica, glosa extratextual y glosa intratextual) a aquellas de sustitución, donde se tiende a la adaptación del elemento cultural (sinonimia, neutralización limitada, neutralización absoluta y naturalización).

La metáfora, recurso retórico por antonomasia desde la antigüedad grecorromana, refleja, pero también construye, las formas de conocer y explicar el mundo por parte de los seres humanos. Dado su carácter cognoscitivo, a través de ellas se dota de comprensibilidad a conceptos nuevos y abstractos a partir de otros existentes y concretos. Si María Moliner (1980, tomo II, 402) define la metáfora como un tropo: «usar las palabras con sentido distinto del que tienen propiamente, pero que guarda con éste una relación descubierta por la imaginación; como "perlas de rocío", "primavera de la vida" », Lakoff y Johnson destacan la base experiencial cultural de las metáforas al afirmar que toda experiencia es profunda e intrínsecamente cultural (Lakoff y Johnson 1986).

Los modismos son unidades simbólicas y, desde el punto de vista cognitivo, se hallan intrínsecamente relacionados con la metáfora, la metonimia y el conocimiento convencional. Puesto que cualquier metáfora desempeña una función cognoscitiva al actuar de vehículo para el intercambio de verdades, creencias u opiniones, el acceso al significado figurado de los modismos lo permite precisamente el conocimiento tácito que el hablante de una lengua posee en torno a las metáforas estructurales subyacentes.

La polémica en torno a la traducibilidad o al grado de traducibilidad de las diversas tipologías de metáforas es una cuestión harto explorada en la lingüística, donde a lo largo de la historia podemos encontrarnos básicamente con cuatro posturas: la metáfora como forma no trasvasable a otra lengua y solo susceptible de ser explicada, dado el carácter anisomórfico y taxonómico de las lenguas; la metáfora como un elemento más de la traducción que ni plantea problemas específicos ni exige abordajes ad hoc;

Peng Liu y Ana M. GonzÁlez Fernández La relevancia epistemológica de la perspectiva cultural y cosmovisión subyacente en los modismos...
CLINA

vol. 6-1, June 2020, 127-146

elSSN: 2444-1961

Ediciones Universidad de Salamanca - CC BY-NC-ND 
la metáfora como portadora de alta inequivalencia interlingüística, traducible, no obstante, a pesar de las dificultades específicas que plantea; la metáfora como elemento cuya traducibilidad/intraducibilidad no depende de su propia naturaleza sino, entre otros factores, del entorno lingüístico en el que se inserta.

Así pues, en lo que parece existir consenso general es en que en cada sociedad se dispone de formas idiosincrásicas de conocer el mundo, de acercamientos perceptivos propios que se reflejan ambos en distintas metáforas, las cuales se destacan y corporizan en los modismos. Por lo tanto, los modismos de diferentes lenguas atesoran cristalizaciones de particulares metáforas estructurales, causando una divergencia entre los modelos cognitivos y lógicos. De acuerdo con la perspectiva empírica sobre el significado de Lakoff y Johnson (1986), el significado no es aislable de los procesos cognitivos del ser humano. Bajo diferentes procesos cognitivos, el ser humano deducirá diferentes significados. Las metáforas son, en definitiva, modelos conductuales, epistemológicos y sensoriales; enuncian la cultura, pero también la crean. Por lo tanto, en muchos casos, resultará adecuado traducir los modismos españoles con un modismo chino similar empleando estrategias de domesticación. Por un lado, cediendo levemente a aquella definición de traducción como canibalismo (Vieira 1994), abandonar las imágenes y las estructuras lingüísticas del modismo español y recurrir a las del modismo chino puede permitir alcanzar la equivalencia de significado, lo cual puede ser clave para provocar una comunicación eficaz entre hablante y lector/receptor. Por otro lado, usar la forma lingüística del modismo también en la traducción presenta como ventaja la de conseguir la equivalencia estilística.

Larson (1989, 151-152) sintetiza también los escollos que encontraríamos con una traducción literal de las metáforas:

Hay varias razones por las que es difícil entender las metáforas y por las que no pueden traducirse literalmente. En primer lugar, la imagen empleada en la metáfora o en el símil puede ser desconocida en la lengua receptora (...) El hecho de que el tópico de la metáfora no siempre esté expresado claramente puede crear otro problema (...) [A] veces el punto de semejanza queda implícito y, por tanto, difícil de entender (...) Uno de los problemas más graves es el hecho de que el punto de semejanza puede entenderse de maneras diferentes en culturas distintas. Se puede atribuir significados distintos a una misma imagen. (...) También es posible que en la lengua receptora no existan comparaciones del tipo que se da en la metáfora del texto original.

He aquí unos ejemplos de traducción español-chino de modismos con la estrategia de domesticación:

(1)【ES】 Antes era de izquierdas y ahora milita en un partido de derechas: qué fácil le resultó cambiar de chaqueta.

【CN】之前他是左翼人士，现在又加入一个右翼党派。改旗易帜/改换门庭对他 来说多么容易!

Peng Liu y Ana M. González Fernández La relevancia epistemológica de la perspectiva cultural y cosmovisión subyacente en los modismos...
CLINA

vol. 6-1, June 2020, 127-146

elSSN: 2444-1961

Ediciones Universidad de Salamanca - CC BY-NC-ND 
(2)【ES】La policía lleva años tratando de echarle el guante a ese estafador.

【CN】警察花数年时间试图将那个诈骗犯绳之以法。

(3)【ES】 En esta familia, quien lleva los pantalones es la abuela.

【CN】在这个家里, 拍板的人是奶奶。

(4)【ES】 Has hecho un análisis fantástico, jme quito el sombrero!

【CN】你做了一个精彩的分析，我五体投地!

(5)【ES】 Para aprobar el difícil examen, debes mojar la camiseta.

【CN】为了通过那个很难的考试，你应该撸起袖子准备。

(6)【ES】Para entender su reacción, tendrás que ponerte en sus zapatos.

【CN】为了理解他的反应，你应该将心比心。

(7)【ES】 No le duelen prendas a la hora de aplicar el nuevo reglamento interno de la empresa.

【CN】公司在执行新的内部规章时不惜血本。

En los siete ejemplos proporcionados arriba, las metáforas estructurales encubiertas en los modismos españoles realmente no existen en los modelos cognitivos y lógicos de los hablantes chinos. Dicho de otro modo, el mecanismo psicológico forjado en la mente de los hablantes españoles y compartido de forma mayoritaria les permite a estos deducir el significado pragmático de las formas lingüísticas presentes en los modismos y las metáforas que portan; sin embargo, sin la existencia de dicho mecanismo particular, el hablante chino no podrá deducir con precisión el significado que se expresa y en muchos casos, al contrario, solo entenderá su significado literal, lo que lo sumergirá en la extrañeza e incomprensibilidad.

Por ejemplo, al enfrentarse a la lectura de una traducción literal de la frase en español «En esta familia, quien lleva los pantalones es la abuela», la primera impresión del lector chino será que alguien de la familia mueve o transporta de un lugar a otro los pantalones, lo cual por otra parte se entendería como un acto normal y cotidiano de una anciana cualquiera que realiza tareas del hogar. La razón por la que el chino no captará el significado de «ostentar el mando» de este modismo español es que los «pantalones», en su modelo cognitivo y lógico, no son considerados símbolos de mando o poder; no se asocia connotativamente esta prenda con la jerarquía (recordemos que, en Europa, a partir del siglo XIX, en una sociedad androcéntrica y patriarcal, el pantalón se asocia definitivamente al vestuario masculino, convirtiéndose consecuentemente en símbolo de esa masculinidad ostentadora del poder). Es decir, sin el marco metafórico "pantalones-poder», con una traducción literal el lector chino probablemente solo alcanzará a entender el significado explicativo en vez del implicativo, lo cual derivará a todas luces en una compresión errónea de la información, en un malentendido, cuando no en la hilaridad, en la medida en que la diferencia entre estos marcos es susceptible de convertirse en una fuente de humor, pues niega el acceso al marco

Peng Liu y Ana M. González Fernández La relevancia epistemológica de la perspectiva cultural y cosmovisión subyacente en los modismos...
CLINA

vol. 6-1, June 2020, 127-146

elSSN: 2444-1961

Ediciones Universidad de Salamanca - CC BY-NC-ND 
que se pretende evocar, como sugiere la exhortación «Don't think of an elephant!» que da título a una de las obras de Lakoff (2004).

Para alcanzar equivalencias tanto en el plano del significado como estilístico, puede ser conveniente adoptar la estrategia de domesticación, así que podemos optar por traducir el modismo citado de «llevar los pantalones» con el modismo chino 拍板, el cual contiene un marco metafórico propio que el hablante nativo chino identifica sin dificultad con «claqueta-poder» y que, desde la diferencia referencial asociativa y metafórica, expresa sin ambigüedades el mismo significado implicativo.

Otro ejemplo: cuando un lector chino lee una traducción literal de la frase en español «La policía lleva años tratando de echarle el guante a ese estafador», lo que probablemente le suscitará en el primer momento será más bien una pregunta curiosa, lejos de llevarle a captar correctamente la información que en realidad quiere transmitir esta oración. Dicha curiosidad o extrañamiento pasará por interrogarse por qué la policía intenta echarle al estafador, en vez de esposas, un guante, una prenda que, según el modelo cognitivo de los chinos, no tiene relación con un contexto propio del ámbito antidelictivo o policial. Para el hablante chino, el guante es un objeto de uso diario que satisface simplemente determinadas necesidades. Sin embargo, con el marco metafórico «guante-prisión» que perciben los hispanohablantes gracias a su trasfondo cultural, les resulta fácil lograr entender tanto el significado explicativo del modismo «echarle el guante» como el implicativo, que es «apresar a una persona, especialmente a un delincuente». Debido a la falta de dicho marco metafórico, el lector chino solo comprende el significado explicativo de esta frase, y fracasa en la captación de la información derivada del sentido figurado. Para subsanar este problema de comunicación, puede ser adecuado utilizar la estrategia de domesticación, de modo que se puede optar por traducir el modismo español con el chino 绳之以法 ( «echar la cuerda según la ley», es decir, "conducir a alguien ante la justicia», que contiene un marco metafórico particular y reconocible para el nativo chino, el de "cuerda-prisión»). Con esta estrategia de domesticación, la frase china traducida expresa el mismo significado implicativo que el enunciado español con el que abríamos el párrafo.

Una situación idéntica la encontramos en el caso de la traducción del español al chino de la frase "Para aprobar el difícil examen, debes mojar la camiseta». Para el lector chino, la acción de mojar la camiseta y la meta de aprobar el difícil examen se encuentran lejos de mantener una relación de causalidad. Solo de añadírsele otra condición especificativa, la de «mojar con sudor», que la acote, el lector chino alcanzará a construir el marco metafórico "camiseta-trabajo/energía» que reconocen los hablantes de la lengua de origen gracias al modelo cognitivo que existe en su mente, y logrará, así, entender el significado implicativo del modismo español, que es "esforzarse», "luchar por conseguir algo". Es decir, mientras los hablantes españoles se valen de su propio marco metafórico para captar la información que quiere transmitir la frase, los lectores chinos carecen de él, lo cual derivará indudablemente en la incomprensibilidad. Para superar este obstáculo cognitivo, puede ser conveniente introducir el marco metafórico frecuente para los hablantes de la lengua meta «manga-trabajo/energía»,

Peng Liu y Ana M. González Fernández La relevancia epistemológica de la perspectiva cultural y cosmovisión subyacente en los modismos...
CLINA

vol. 6-1, June 2020, 127-146

elSSN: 2444-1961

Ediciones Universidad de Salamanca - CC BY-NC-ND 
que por ejemplo se refleja en el modismo chino 撸起袖子 («subirse las mangas», «arremangarse») y que transmite idéntico significado implicativo.

Sin embargo, huelga dejar constancia de que si los modismos en chino y español, por casualidad, compartiesen idéntica metáfora estructural, podrá resultar adecuado adoptar el método de traducción literal que en ciertas ocasiones se utiliza dentro de estrategias de extranjerización, con el fin de que el lector/receptor también pueda deducir el significado que expresa el modismo de la lengua de origen gracias a que se comparte el marco metafórico. Derivada de esta condición, la traducción literal reporta una ventaja evidente: el lector de la lengua meta, a través de la lectura de un modismo ya existente en su lengua, podrá ahorrar esfuerzo cognitivo a la hora de comprender el significado que expresa el modismo español, lo cual, dada esta intersección de marcos, también facilita una mayor eficiencia en la comunicación intercultural entre interlocutores de estos dos idiomas.

(8)【ES】 Si quieres llegar a final de mes, tienes que apretarte el cinturón y no volverte loco en las rebajas.

【CN】traducción literal: 如果你想撑到月底，你应该勒紧裤腰带，不要痴迷于那 些打折活动。

【CN】 traducción mediante paráfrasis: 如果你想撑到月底，你应该节省开支，不 要痴迷于那些打折活动。

En este caso, en el que, como hemos señalado, el hablante español y el lector chino comparten la metáfora estructural «cinturón-autocontrol o autorrestricción», el modismo chino 勒紧裤腰带 («ajustarse el cinturón»), al identificarse con el modelo cognitivo del hablante español, transmite el mismo significado al lector chino: reducir o ajustar el gasto en un proceso de autocontrol o restricción autoimpuesta o condicionada por las circunstancias. Por lo tanto, la traducción literal, que en muchas ocasiones se emplea en una estrategia de extranjerización, podrá resultar mejor que una traducción parafrástica, que en ocasiones se utiliza como estrategia de domesticación.

Por ejemplo, la opción parafrástica 节省开支 (《ahorrar o aplicar recortes»), si bien presenta directamente el significado al lector meta, no aprovecha la oportunidad de darle a conocer que, efectivamente, existe una convergencia conceptual cultural entre los dos pueblos. Además, la traducción literal en este caso también emplea la forma lingüística del modismo para expresar el mismo significado, así que cumple satisfactoriamente con el requisito de equivalencia estilística de la traducción.

(9)【ES】Los líos de faldas del embajador acabaron con su carrera.

【CN】 traducción literal: 那位大使惹的裙下麻烦终结了他的职业生涯。

【CN】traducción mediante paráfrasis: 那位大使因为与多位女人纠缠带来的麻烦 终结了他的职业生涯。

En este caso, para traducir el modismo español «líos de faldas» al chino, nos encontramos con dos opciones: primero, la traducción a través de una paráfrasis: 与多

Peng Liu y Ana M. González Fernández La relevancia epistemológica de la perspectiva cultural y cosmovisión subyacente en los modismos... 
位女人调情带来的麻烦 (《líos causados por el acto de coquetear con diversas mujeres bellas»); segundo, la traducción literal: 裙下麻烦 («líos bajo la falda»). Con la leyenda de la concubina Yang como contexto enciclopédico, el lector de la lengua meta, al ver la expresión en chino, activará en su mente la metáfora estructural ya existente en su cultura de «faldas-mujer bella» y así deducirá sin obstáculos el significado real que quiere transmitir el modismo español, que se refiere a aquellas situaciones problemáticas en las que se ve envuelto un varón por una suerte de donjuanismo que se pone de manifiesto en una afición desmedida a las aventuras con mujeres. Por lo tanto, la traducción literal, en este caso, ahorrará al lector de la lengua meta esfuerzo cognitivo.

Así pues, pese a que, en determinados casos, pueda ser conveniente el empleo de estrategias de domesticación en aras de una mayor fluidez y un menor grado de extrañamiento, también somos conscientes de que, por un lado, con ellas se fomenta la invisibilización del traductor, un concepto recurrente y extensamente desarrollado por Venuti (1995) y, por otro, se corre un excesivo riesgo de etnocentrismo que, además, cubre de opacidad la cultura de la lengua de origen, pues alimenta la ilusión en el receptor de que no se halla ante una traducción y hace que pasen desapercibidos, en consecuencia, ciertos sabores y aromas idiosincrásicos de la otra cultura. De aquí que, a fin de permitir al traductor cumplir convenientemente con su papel de agente mediador y modulador, defendemos también la utilización de una transliteración recogida a pie de página o en apéndice (glosas extratextuales), al considerar que constituye una ventana de la que no debe privarse necesariamente al lector. Aun en el más neófito, esta operativa es susceptible de suscitar una reflexión y un deleite intelectual o estético a los que no sería lícito obligarle a renunciar. En este sentido, en una era de premuras donde se acostumbra y envicia al lector en la inmediatez acrítica e irreflexiva, una pausa que le permita acercarse a las expresiones originales, a los elementos que integran ese modismo y que reflejan una peculiar y, por qué no, exótica visión del mundo, debe también considerarse con el fin de hacer todos estos elementos accesibles al lector, si no directamente en la traducción, sí a pie de página o en una suerte de glosario final, dándole así la oportunidad de incrementar su acervo cultural y desarrollar su competencia intercultural.

Lu Xun (鲁迅) (1980), acérrimo defensor de la extranjerización como estrategia, conceptualizaba la traducción de los culturemas foráneos como un viaje a escenarios exóticos y desconocidos que el receptor no debía perderse. Para ello, proponía recurrir, entre otros recursos, a calcos o préstamos. Concordamos con él en la importancia del «viaje», del "sentirse trasladado", para lo cual puede ser importante mantener ciertos conceptos clave y privativos de la cultura de la lengua de origen. Hoy en día, por ejemplo, puesto que ya están relativamente popularizados entre la población hispanohablante, a prácticamente ningún traductor se le ocurriría traducir conceptos tan axiómáticos de la cultura china como guanxi (关系, «capital relacional») o mianzi (面子, «acervo reputacional»).

Llegados a este punto, a partir del análisis arriba expuesto, se podría proponer como conclusión esta estrategia de traducción: la decisión de si optar por la estrategia

Peng Liu y Ana M. González FernándeZ La relevancia epistemológica de la perspectiva cultural y cosmovisión subyacente en los modismos...
CLINA

vol. 6-1, June 2020, 127-146

elSSN: 2444-1961

Ediciones Universidad de Salamanca - CC BY-NC-ND 
de extranjerización o por la de domesticación podrá depender de si el marco metafórico contenido en la información de la lengua de origen es coherente con el de la lengua meta. De ser coherente, se puede optar por una traducción basada en la literalidad. Si no hay coherencia o falta el marco metafórico correspondiente en el idioma de destino, puede ser altamente recomendable traducir a través de paráfrasis, aunque también podrán explorarse opciones para que el lector de la lengua meta tenga la oportunidad de percibir la cosmovisión que constituye la mejor tarjeta de presentación del pueblo de la lengua de origen, por ejemplo, como ya señalábamos, a través de notas a pie de página o glosarios finales.

\section{CONCLUSIÓN}

Como pauta general, casi axiomática, el traductor debe seleccionar cierta forma lingüística de la lengua meta a fin de transmitir en el mayor grado posible el significado presente en el texto de la lengua de origen, con el objetivo de lograr una equivalencia semántica básica.

Sin embargo, cuando este traductor se enfrenta con la traducción de modismos, cuyos significados no resultan fácilmente deducibles a partir de las palabras que los conforman, han de considerarse también necesariamente la relevancia cultural y ciertos factores extratextuales en aras de la efectividad comunicativa, en vista del hecho de que estos modismos reflejan hábitos, conceptos o experiencias únicas de un pueblo, los cuales, a menudo, no se identifican con los del otro pueblo.

Por lo tanto, la traducción de modismos requiere la identificación, comprensión e interiorización de la perspectiva cultural del colectivo humano hablante de esa lengua y de su cosmovisión, valores o creencias básicas, de modo que la decisión de optar por estrategias de extranjerización o por otras de domesticación en la traducción dependerá en buena medida de si el marco metafórico contenido en el modismo de la lengua de origen es coherente con el de la lengua meta.

Además, con el fin de permitir al traductor cumplir convenientemente con su papel de agente mediador y modulador, se aboga por el empleo de la transliteración a pie de página o en apéndice (glosas extratextuales) acompañando a una posible traducción domesticada, con el objetivo de conceder al lector tanto español como chino la oportunidad de incrementar su acervo cultural y desarrollar su competencia intercultural. Tal vez, dada la prevalencia de una globalización que uniformiza, esto sea más necesario que nunca, pues apuesta por la reconstrucción epistemológica y contribuye a ella, a partir de una consciencia de la enriquecedora diversidad de las culturas, lo que, hoy más que nunca, precisa de adalides.

Peng Liu y Ana M. González Fernández La relevancia epistemológica de la perspectiva cultural y cosmovisión subyacente en los modismos...
CLINA

vol. 6-1, June 2020, 127-146

elSSN: 2444-1961

Ediciones Universidad de Salamanca - CC BY-NC-ND 


\section{BIBLIOGRAFÍA}

ARISTóteles. 2009. Categorías. Sobre la interpretación. Buenos Aires: Losada.

Franco AixelÁ, Javier. 1996. "Culture-Specific Items in Translation». En Translation, Power, Subversion, editado por Román Álvarez Rodríguez y África Vidal Claramonte, 52-78. Clevedon: Multilingual Matters.

Hofstede, Geert. 2001. Culture's Consequences: Comparing Values, Behaviors, Institutions and Organizations Across Nations. Netherlands: Tilburg University.

HoIJeR, Harry. 1954. "The Sapir-Whorf Hypothesis». En Language in Culture: Proceedings of a Conference on the Interrelations of Language and Other Aspects, editado por Harry Hoijer, 92-105. Chicago: University Press of Chicago.

HumBoldt, Wilhelm von. 1836. Linguistic Variability and Intellectual Development. Filadelfia: University of Pennsylvania Press.

LAKOFF, George y Mark JoHnson. 1986. Metáforas de la vida cotidiana. Trad. Carmen González Marín. Madrid: Cátedra, 39.

LAKOFF, George. 2004. Don't Think of an Elephant: know your values and frame the debate. The essential guide for progressives. Nueva York: Chelsea Green.

LARSON, Mildred L. 1989. La Traducción basada en el significado. Trad. Donald H. Burns, Rodolfo von Moltke. Buenos Aires: Eudeba, 151-152.

Lu, Xun (鲁迅). 1980. ““题未定” 草 (一至三)》. Lu Xun Quanji [Las obras completas de Lu Xun]》. Beijing: Renmin wenxue chubanshe.

MASUDA, Takahiko y Richard Eugene Nisbett. 2001. "Attending Holistically versus Analytically: comparing the context sensitivity of Japanese and Americans». Journal of Personality and Social Psychology 81: 922-934.

Moliner RuIz, María Juana. 1980. Diccionario de Uso del Español. Madrid: Gredos.

NIDA, Eugene A. 1993. Language, Culture and Translating. Sanghai: Foreign Language Education Press.

Venuti, Lawrence. (1995). The Translator's Invisibility: A History of Translation. Londres: Routledge.

VIEIRA, Else. (1994). Por uma teoria posmoderna da tradução. Tesis Doctoral. Belo Horizonte: Universidade Federal de Minas Gerais.

Peng Liu y Ana M. González Fernández La relevancia epistemológica de la perspectiva cultural y cosmovisión subyacente en los modismos... 